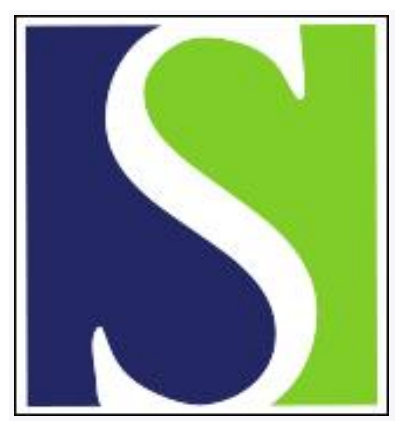

Scand J Work Environ Health 1989;15(6):436-438

https://doi.org/10.5271/sjweh.1829

Issue date: Dec 1989

Ethylene oxide doses in ethene-exposed fruit store workers.

by Tornqvist MA, Almberg JG, Bergmark EN, Nilsson S, Osterman-Golkar SM

Affiliation: Department of Radiobiology, University of Stockholm, Sweden.

This article in PubMed: www.ncbi.nlm.nih.gov/pubmed/2617260

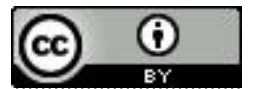




\title{
Ethylene oxide doses in ethene-exposed fruit store workers
}

\author{
by Margareta $\AA$ Törnqvist, PhD, ${ }^{1}$ Jeanette G Almberg, BSc, ${ }^{1}$ Emma N Bergmark, BSc, ${ }^{1}$ \\ Sten Nilsson, ${ }^{2}$ Siv M Osterman-Golkar, $\mathrm{PhD}^{1}$
}

\begin{abstract}
TÖRNQVIST MÅ, ALMBERG JG, BERGMARK EN, NILSSON S, OSTERMAN-GOLKAR SM. Ethylene oxide doses in ethene-exposed fruit store workers. Scand J Work Environ Health 1989;15:436-438. Blood samples from 10 ethene-exposed fruit store workers and 10 referents were analyzed for the level of hydroxyethyl adducts to N-terminal valine in hemoglobin (Hb). A statistically significant difference was obtained between the nonsmoking workers $(N=7)$ and the nonsmoking referents $(N=6)$. This finding demonstrates that ethene is metabolized to ethylene oxide in man. According to this preliminary study, ethene exposure at 0.3 (uncertainty range $0.1-1$ ) ppm during workhours increases the adduct level by $23 \mathrm{pmol} / \mathrm{g} \mathrm{Hb}$. This figure is compatible with a metabolic conversion of $3 \%(1-10 \%)$ of the inhaled ethene to ethylene oxide.
\end{abstract}

Key terms: carcinogen, Edman degradation, gas chromatography-mass spectrometry, hemoglobin adducts, $\mathrm{N}$-alkyl Edman method, occupational exposure.

The determination of adducts in hemoglobin $(\mathrm{Hb})$ is a useful approach for monitoring tissue doses of ultimate carcinogens $(1,2)$, and it provides a basis for risk estimation (3).

The measurement of hydroxyethyl adducts to $\mathrm{N}$ terminal valine in hemoglobin (4) by gas chromatography-mass spectrometry has been used as dosimetry for ethylene oxide in smokers and nonsmokers $(5,6)$. The adduct level in smokers [an increment of about $85 \mathrm{pmol} / \mathrm{g} \mathrm{Hb}$ and 10 cigarettes/d (7)] indicates that the ethene in tobacco smoke may be the source. This hypothesis is based on the assumption that humans and experimental animals metabolize inhaled ethene to ethylene oxide $(8-10)$ and detoxify ethylene oxide (see references 11 and 12) at approximately equal rates or that the ratio of the rates of bioactivation and epoxide detoxification is approximately the same for man and rodents, with the same epoxide dose per milligram of inhaled ethene as a consequence (5).

However, this quantitative agreement between found and expected adduct levels cannot be considered proof that ethene in tobacco smoke is the source of the adducts. Natural metabolites may give rise to hydroxyethyl adducts, ethene may be formed endogenously ( 5 , 13 ), and it cannot be excluded that such processes are affected by smoking in a way that results in increased 2-hydroxyethyl adduct levels. Unequivocal proof that ethene is metabolized to ethylene oxide in humans

\footnotetext{
I Department of Radiobiology, University of Stockholm, Stockholm, Sweden.

2 Företagshälsovårdscentralen, Skår AB, Göteborg, Sweden.
}

Reprint requests to: Dr MẢ Törnqvist, Department of Radiobiology, University of Stockholm, S-106 91, Stockholm, Sweden. could be gained in studies of the adduct level in persons with a specific exposure to ethene. For this purpose employees in a company using ethene for controlling the ripening of bananas were examined with regard to the $N$-(2-hydroxyethyl)valine (HOEtVal) level in their hemoglobin.

\section{Subjects and methods}

Blood samples were obtained from 10 stockroom workers and 10 referents. Data were recorded on exposure to tobacco smoke, urban air pollution, and other conditions that might influence the results. Personal and stationary monitoring of ethene in the workplace was carried out for $2 \mathrm{~d}$ in connection with the blood sampling. The analysis was based on the enrichment of ethene on a solid sorbent (13X, Union Carbide) and subsequent thermal desorption for gas chromatographic analysis. The blood samples were collected in heparinized tubes with gamma-sterilized cannulae. The red cells were recovered by centrifugation and were carefully washed with an $0.9 \%$ sodium chloride solution. The cells were stored at $-70^{\circ} \mathrm{C}$. Globin was precipitated according to the method described by Mowrer et al (14). The samples were analyzed by gas chromatography-mass spectrometry with respect to HOEtVal in hemoglobin by an updated version (10) of the N-alkyl Edman method (4). For practical reasons, the samples from the referents were collected one month later than the samples from the exposed persons, but replicate blood samples from two of the exposed persons were collected at the same time as the reference samples. This repeated sampling was considered necessary as a check that the storage of samples, through artefact formation of HOEtVal, had no influence on the results (15). 


\section{Results and discussion}

The results from the analyses of the HOEtVal levels in hemoglobin and the data on smoking habits are presented in table 1.

A statistically significant difference $(\mathrm{P}<0.01)$ was obtained between the nonsmoking fruit store workers and the nonsmoking referents with respect to the level of HOEtVal in hemoglobin. This result is important since it supports qualitatively the assumption, based on animal experiments and studies on smokers-nonsmokers, that ethene is metabolized to ethylene oxide also in man. Personal and stationary monitoring of ethene in the workplace showed air concentrations in the range of $0.02-3.35 \mathrm{ppm}$, the average concentration being estimated as 0.3 (uncertainty range $0.1-1$ ) ppm. According to this preliminary study, ethene exposure at a level of $0.3 \mathrm{ppm}$ during workhours would thus increase the HOEtVal level by $23 \mathrm{pmol} / \mathrm{g} \mathrm{Hb}$.

With the use of a probable value of the rate of clearance of ethylene oxide in man [approximately $3 \mathrm{~h}^{-1}$ (11)], a ventilation rate of $0.21 \cdot \mathrm{kg}^{-1} \cdot \mathrm{min}^{-1}$, absorption of $80 \%$ of the inhaled amount (16), and a rate constant of $\mathrm{k}=0.45 \cdot 10^{-4} \mathrm{I} \cdot(\mathrm{g} \mathrm{Hb})^{-1} \cdot \mathrm{h}^{-1}(17)$ for the reaction of ethylene oxide with $\mathrm{N}$-terminal valine in hemoglobin, the steady-state level of HOEtVal established during long-term exposure at, eg, $1 \mathrm{ppm}$ of ethylene oxide during workhours is estimated to be $2.2 \mathrm{nmol}\left(\mathrm{g} \mathrm{Hb}^{-1}\right.$. This estimate agrees with determinations of adduct levels in workers well characterized with respect to ethylene oxide exposure $[2.4 \mathrm{nmol}$ HOEtVal/g Hb, corresponding to exposure at $1 \mathrm{ppm}$ for $40 \mathrm{~h} /$ week (12)].

Accordingly 1 ppm of ethene in ambient air would give rise to the same adduct level as 0.03 (range $0.01-$ $0.1) \mathrm{ppm}$ of ethylene oxide and would correspond to a conversion rate of $3 \%$. Cigarette smokers have been estimated to convert about $6 \%$ of the inhaled ethene to ethylene oxide $(5,7)$. This value falls within the interval found in the present study. For attaining a more accurate value for the conversion rate - useful for the hygienic surveillance of work environments and for risk assessment - studies with a better characterization of exposure doses are required.

A comparison of exposed and unexposed smokers indicates that the former exhibit a larger adduct level increment per cigarette and gram of hemoglobin (15.7 pmol) than the latter $(9.3 \mathrm{pmol})$, and, in fact, a t-test showed this difference to be weakly significant $(\mathrm{P}=0.02)$. A difference of this kind would apply if the system bioactivating ethene is induced in smokers. This possibility, of importance to risk assessment, will be subjected to further studies.

\section{Acknowledgments}

We are grateful to Professor L Ehrenberg for his valuable viewpoints. The study was supported financially by the Swedish Work Environment Fund, Shell Inter-
Table 1. Degree of $N$-2-hydroxyethylation of $\mathrm{N}$-terminal valine (HOEtVal) in the hemoglobin of workers with occupational exposure to ethene and in the hemoglobin of referents.

\begin{tabular}{|c|c|c|c|}
\hline \multirow{2}{*}{ Subject } & \multirow{2}{*}{$\begin{array}{l}\text { Smoking habits } \\
\text { (cigarettesid) }\end{array}$} & \multicolumn{2}{|c|}{ is HOEtVala (pmol/g hemoglobin) } \\
\hline & & Individual ${ }^{b}$ & Average \\
\hline \multicolumn{4}{|l|}{$\begin{array}{l}\text { Ethene-exposed } \\
\text { subjects }\end{array}$} \\
\hline $\begin{array}{l}2 \\
3 \\
4 \\
5 \\
5 a \text { (replicate } \\
\text { sample) } \\
7 \\
7 a \text { (replicate } \\
\text { sample) } \\
8 \\
10\end{array}$ & $\begin{array}{l}\text { Nonsmoker } \\
\text { Nonsmoker } \\
\text { Nonsmoker } \\
\text { Nonsmoker } \\
\text { Nonsmoker } \\
\text { Nonsmoker } \\
\text { Nonsmoker } \\
\\
\text { Nonsmoker } \\
\text { Nonsmoker }\end{array}$ & $\begin{array}{l}52 \\
42 \\
22 \\
28 \\
42>35 \\
47 \\
52>50 \\
65 \\
34\end{array}$ & 43 \\
\hline $\begin{array}{l}1 \\
6 \\
9\end{array}$ & $\begin{array}{l}15 \\
10-20 \\
15-20\end{array}$ & $\begin{array}{l}234 \\
254 \\
360\end{array}$ & 283 \\
\hline \multicolumn{4}{|l|}{ IReferents } \\
\hline $\begin{array}{l}B \\
E \\
F \\
G \\
H \\
I\end{array}$ & $\begin{array}{l}\text { Nonsmoker } \\
\text { Nonsmoker } \\
\text { Nonsmoker } \\
\text { Nonsmoker } \\
\text { Nonsmoker } \\
\text { Nonsmoker }\end{array}$ & $\begin{array}{l}23 \\
27 \\
27 \\
17 \\
16 \\
12\end{array}$ & 20 \\
\hline $\begin{array}{l}A \\
C \\
J \\
D\end{array}$ & $\begin{array}{l}10-15 \\
20 \\
15 \\
6+\text { pipe }\end{array}$ & $\begin{array}{l}129 \\
229 \\
149 \\
251\end{array}$ & $169 c$ \\
\hline
\end{tabular}

ia HOEtVal $=N$-(2-hydroxyethyl)valine.

to The values are based on one analysis. For reproducibility and calibration, see reference 10.

(c) The person smoking both cigarettes and a pipe excluded.

nationale Research Maatschappij BV, and the National Swedish Environment Protection Board.

\section{References}

1. Ehrenberg L, Osterman-Golkar S. Alkylation of macromolecules for detecting mutagenic agents. Teratogenesis Carcinog Mutagen 1980;1:105-27.

2. Farmer PB, Neumann H-G, Henschler D. Estimation of exposure of man to substances reacting covalently with macromolecules. Arch Toxicol 1987;60:251-60.

3. Ehrenberg L, Moustacchi E, Osterman-Golkar S. Dosimetry of genotoxic agents and dose-response relationships of their effects. Mutat Res 1983;123:121 - 82.

4. Törnquist M, Mowrer J, Jensen S, Ehrenberg L. Monitoring of environmental cancer initiators through hemoglobin adducts by a modified Edman degradation method. Anal Biochem 1986;154:255-66.

5. Törnqvist M, Osterman-Golkar S, Kautiainen A, Jensen S, Farmer PB, Ehrenberg L. Tissue doses of ethylene oxide in cigarette smokers determined from adduct levels in hemoglobin. Carcinogenesis 1986;7:1519-21.

6. Bailey E, Brooks AGF, Dollery CT, et al. Hydroxyethylvaline adduct formation in haemoglobin as a biological monitor of cigarette smoke intake. Arch Toxicol $1988 ; 62: 247-53$.

7. Törnqvist M. Monitoring and cancer risk assessment of carcinogens, particularly alkenes in urban air [Doctoral dissertation]. Stockholm: University of Stockholm, 1989.

8. Osterman-Golkar S, Ehrenberg L. Covalent binding of reactive intermediates to hemoglobin as an approach for determining the metabolic activation of chemicals - ethylene. Drug Metab Rev 1982;13:647-60.

9. Segerbäck D. Alkylation of DNA and hemoglobin in the mouse following exposure to ethene and ethene 
oxide. Chem Biol Interact 1983;45:139-51.

10. Törnqvist M, Kautiainen A, Gatz RN, Ehrenberg L. Hemoglobin adducts in animals exposed to gasoline and diesel exhausts: I. alkenes. J Appl Toxicol 1988;8: 159-70.

11. Osterman-Golkar S, Bergmark E. Occupational exposure to ethylene oxide: relation between in vivo dose and exposure dose. Scand $\mathrm{J}$ Work Environ Health $1988 ; 14: 372-7$.

12. Duus U, Osterman-Golkar S, Törnqvist M, Mowrer J, Holm S, Ehrenberg L. Studies of determinants of tissue dose and cancer risk from ethylene oxide exposure. In: Freij L, ed. Proceedings of the symposium on management of risk from genotoxic substances in the environment. Solna (Sweden): Swedish National Chemicals Inspectorate, 1989:141-53.

13. Törnqvist M, Gustafsson B, Kautiainen A, HarmsRingdahl M, Granath F, Ehrenberg L. Unsaturated lipids and intestinal bacteria as sources of endogenous production of ethene and ethylene oxide. Carcinogenesis $1989 ; 10: 39-41$.

14. Mowrer J, Törnqvist M, Jensen S, Ehrenberg L. Modified Edman degradation applied to hemoglobin for monitoring occupational exposure to alkylating agents. Toxicol Environ Chem 1986;11:215-31.

15. Törnqvist M. Formation of reactive species that lead to hemoglobin adducts during storage of blood samples. Carcinogenesis (in press).

16. Brugnone F, Perbellini L, Faccini GB, Pasini F, Bartolucci GB, DeRosa E. Ethylene oxide exposure: bio logical monitoring by analysis of alveolar air and blood. Int Arch Occup Environ Health 1986;58:105-12.

17. Segerbäck D. In vivo dosimetry of some alkylating agents as a basis for risk estimation [Doctoral dissertation]. Stockholm: University of Stockholm, 1985.

Received for publication: 18 September 1989 